Sharif University of Technology
Scientia Iranica
SCIENTIA
I RAN I CA

Research Note

\title{
Sustainable urban design; past, present, and future Case study: Darabad River Valley
}

\author{
M.R. Pourjafar ${ }^{\mathrm{a}, *}$ and A. Pourjafar ${ }^{\mathrm{b}}$ \\ a. Faculty of Art \& Architecture, Tarbiat Modares University, Tehran, Iran. \\ b. Faculty of Art \& Architecture, Department of Urban \& Regional Planning \& Urban Design, Tarbiat Modares University, Tehran, \\ Iran.
}

Received 11 May 2015; received in revised form 27 June 2015; accepted 30 January 2016

\section{KEYWORDS}

Sustainability;

Urban environmental

design;

Darabad River Valley.

\begin{abstract}
The rapid and uncontrolled haphazard urbanization is a serious threat to the manmade and natural environment and the socio-economic balance of our time. There is a global concern that urbanization must be oriented in responsible, sustainable, and livable urban forms. High quality of sustainable urban design plays a key role in creating these sustainable living environments. In this regard, learning from culture and history and searching together are vital for new ways of designing. In this paper, the evolution of the settlements with respect to sustainable urban design in past, present, and future is analyzed. The study indicates that we had sustainable urban design in pre-industrial period in an organic way; however, we altered the existing ecosystems by welcoming incompatible technological elements; elements that cause a kind of ill growth similar to cancer. In this relation, a case study of urban environmental design for Darabad River Valley in Tehran as a sustainable urban design project is presented briefly. Finally, it is concluded that we should know that designing is a kind of altering the systems. A comprehensive wise and conscious approach similar to what we have used in Darabad River Valley project is suggested for similar situations.
\end{abstract}

(C) 2016 Sharif University of Technology. All rights reserved.

\section{Introduction}

Human being's instinct to live in an urban area, dependence on others for the basic needs, and the urge to share all bear testimony to the fact that human is a social animal. History reveals that the metamorphosis of man from hunter to cultivator compelled him to lead a settled life in a social community form. Community life has been reflected by different lights during the past eras, subject to environmental, physical, economic and social norms of the time. The automobile free traffic resulted in the growth of small self-sufficient communities, with good social interaction and special respect

\footnotetext{
*. Corresponding author. Tel.: +9821 82883731;

Fax: +982182883731

E-mail address: pourja_m@modares.ac.ir (M.R. Pourjafar)
}

for natural surroundings [1]. In the pre-industrial societies, men, methods, and materials determined the size and morphology of the settlements. The method and materials were very simple. Thus, the urban form reflected human scale. With the advent of the Industrial Revolution, the machine brought about a total change in the living and settlement pattern. As the industry pulled a lot of people from the rural areas, the urban areas acquired a new identity; thus, their social, economic, political, and physical characteristics altered. They generated slums. In fact, many urban slums with all kinds of pollution were created. This urban decay was the breeding ground for new patterns, many of which were not compatible with the basic requirements and ecological potential of the inhabitants and their site (Figure 1 and Table 1 ). In this paper, the case study of Darabad River Valley in Tehran with 


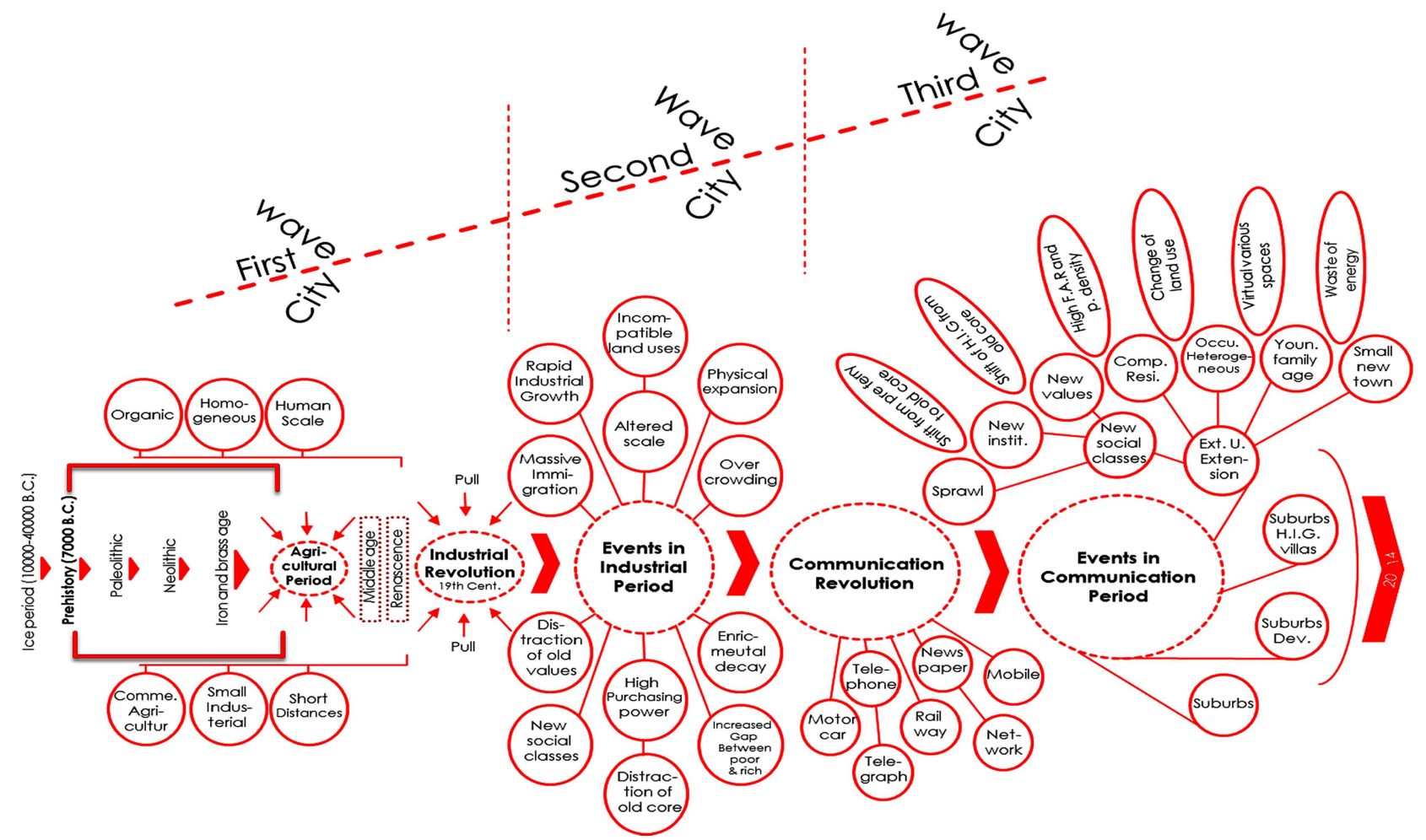

Figure 1. Evolution of human settlement (please refer to Table 1).

high environmental quality, which was about to convert into a huge polluted urban drain, is presented.

\section{Material and methods}

Here, a case study entitled Sustainable Urban Environmental Design for Darabad River Valley located in north-east of Tehran is presented in brief.

To study the river valley of Darabad, three stages of study, analysis, and proposals were followed. The main headings of the research are listed below:

1. Defining the scope of various zones for studying existing situation;

2. History of the place;

3. Study of similar cases;

4. Geology and geophysics of the area, morphology, topography, and physiology;

5. Hydrology, flood pattern, and climatology study;

6. Environmental studies and various pollutions;

7. Green spaces, open spaces, and urban spaces;

8. Animals and birds;

9. Population and socio-economic aspects;

10. Land ownership;

11. Tourism, recreation, and their requirements;

12. Urban planning and urban design studies;
13. Landscape studies and features;

14. Traffic and circulation system;

15. Various proposed plans at higher level and the influence zone (Such as Tehran Master Plan, etc.);

16. Infrastructures;

17. Site analysis (action area);

18. Various analyses of the abovementioned aspects and preparation of 17 SOWT table for each and every subject;

19. Synthesis of the study;

20. Aim, objective, and ideas;

21. Strategy, policies proposals;

22. Design criteria for each zone;

23. Typical design solution.

\section{Results}

The result of the above discussion indicates that we had sustainable urban design in pre-industrial period in an organic way. However, we altered the existing ecosystems by welcoming incompatible technological elements; now and then, we should realize our previous mistakes and do not alter any organic and surviving fabric without comprehensive deep study. We should know that designing is a kind of altering the systems. The design of our towns and cities must concentrate on not only making them visually attractive, but also 
Table 1. Comparative analysis of various features of settlements in pre-industrial, industrial, and post-industrial periods (with reference to Figure 1).

\begin{tabular}{|c|c|c|c|}
\hline No. & $\begin{array}{l}\text { The first city } \\
\text { Pre-industrial } \\
\text { properties }\end{array}$ & $\begin{array}{c}\text { The second city } \\
\text { Industrial period } \\
\text { properties }\end{array}$ & $\begin{array}{c}\text { The third city } \\
\text { Post-industrial period } \\
\text { properties }\end{array}$ \\
\hline 1 & $\begin{array}{l}\text { Organic \& normal growth } \\
\text { (according to physical and } \\
\text { ecological potential) }\end{array}$ & $\begin{array}{l}\text { Imposed development by } \\
\text { master plan and start of } \\
\text { acceleration urbanization }\end{array}$ & $\begin{array}{l}\text { Rigid zoning (completely } \\
\text { residential, commercial etc.), } \\
\text { suburb occupation \& } \\
\text { urbanization of rural areas }\end{array}$ \\
\hline 2 & $\begin{array}{l}\text { Normal gap between } \\
\text { rich and poor }\end{array}$ & $\begin{array}{l}\text { Increasing gap } \\
\text { between rich and poor }\end{array}$ & $\begin{array}{l}\text { Highly increased gap } \\
\text { between rich and poor } \\
(99 \%-1 \%)\end{array}$ \\
\hline 3 & $\begin{array}{l}\text { Harmony between manmade } \\
\text { and natural environment; } \\
\text { fine grain uniform } \\
\text { texture of built form }\end{array}$ & $\begin{array}{l}\text { Lose of harmony between } \\
\text { manmade and natural } \\
\text { environment; coarse } \\
\text { grain \& uniform texture } \\
\text { of built form }\end{array}$ & $\begin{array}{l}\text { Contrast between manmade } \\
\text { and natural environment; } \\
\text { coarse grain \& uneven } \\
\text { texture of built form }\end{array}$ \\
\hline 4 & $\begin{array}{l}\text { Low media of } \\
\text { communication }\end{array}$ & $\begin{array}{l}\text { Average media of } \\
\text { communication }\end{array}$ & $\begin{array}{l}\text { Fast-forward media } \\
\text { of communication }\end{array}$ \\
\hline 5 & No traffic problem & Traffic jam and hazard & High traffic jam and hazard \\
\hline 6 & $\begin{array}{l}\text { Long time taking } \\
\text { communication }\end{array}$ & $\begin{array}{l}\text { Average time } \\
\text { taking communication }\end{array}$ & $\begin{array}{l}\text { High and fast media of soft } \\
\text { and hard wire communication }\end{array}$ \\
\hline 7 & $\begin{array}{l}\text { No video } \\
\text { ecological damage }\end{array}$ & $\begin{array}{l}\text { Low video } \\
\text { ecological damage }\end{array}$ & High video ecological damage \\
\hline 8 & $\begin{array}{l}\text { Carbon free } \\
\text { settlements }\end{array}$ & $\begin{array}{l}\text { Micro level } \\
\text { carbon problem }\end{array}$ & $\begin{array}{l}\text { Macro level carbon problem } \\
\text { (damage of ozone layer) }\end{array}$ \\
\hline 9 & $\begin{array}{l}\text { Physical human } \\
\text { public spaces }\end{array}$ & $\begin{array}{l}\text { Physical human and } \\
\text { automobile public spaces }\end{array}$ & Virtual spaces \\
\hline 10 & $\begin{array}{l}\text { Spiritual settlements } \\
\text { with strong elements and } \\
\text { landmarks of cultural } \\
\text { values }\end{array}$ & $\begin{array}{l}\text { Weak spiritual aspect and } \\
\text { weak cultural values }\end{array}$ & $\begin{array}{l}\text { Lost spiritual aspect } \\
\text { and cultural values }\end{array}$ \\
\hline 11 & $\begin{array}{l}\text { Low damage to } \\
\text { the environment }\end{array}$ & $\begin{array}{l}\text { Micro level damage to } \\
\text { the environment }\end{array}$ & $\begin{array}{l}\text { Macro level damage } \\
\text { to the environment }\end{array}$ \\
\hline 12 & $\begin{array}{l}\text { Human scale } \\
\text { corridors, pathways } \\
\& \text { and nodes }\end{array}$ & $\begin{array}{l}\text { Bolvards, high ways } \\
\text { and freeways \& } \\
\text { expanding old pathways }\end{array}$ & $\begin{array}{l}\text { Elevated high ways, } \\
\text { underground corridors } \\
\text { and nodes }\end{array}$ \\
\hline 13 & $\begin{array}{l}\text { Pallet of monochrome } \\
\text { and harmonic colors }\end{array}$ & Pallet of contrast colors & $\begin{array}{l}\text { Pallet of high } \\
\text { level of contrast colors }\end{array}$ \\
\hline 14 & $\begin{array}{l}\text { Local traditional } \\
\text { production }\end{array}$ & $\begin{array}{l}\text { Standardization, mechanization, } \\
\text { prefabrication, industrialization } \\
\text { and modern mass production } \\
\text { for regional consumption }\end{array}$ & $\begin{array}{l}\text { Mass production for } \\
\text { global consumption }\end{array}$ \\
\hline 15 & $\begin{array}{l}\text { Homogeneous } \\
\text { limited society } \\
\text { (feudal) } \\
\end{array}$ & $\begin{array}{l}\text { Heterogeneous and new } \\
\text { social classes }\end{array}$ & $\begin{array}{l}\text { New social } \\
\text { classes (network holder) }\end{array}$ \\
\hline 16 & Unipolar powers & $\begin{array}{l}\text { Bipolar powers } \\
\text { (capitalist \& socialist) }\end{array}$ & Multipolar powers \\
\hline 17 & $\begin{array}{l}\text { Soft areas dominating } \\
\text { landscape }\end{array}$ & $\begin{array}{l}\text { Soft areas and environmental } \\
\text { decay and decreasing soft } \\
\text { green areas }\end{array}$ & $\begin{array}{l}\text { Hard areas } \\
\text { dominating landscape }\end{array}$ \\
\hline
\end{tabular}


Table 1. Comparative analysis of various features of settlements in pre-industrial, industrial, and post-industrial periods (with reference to Figure 1) (continued).

\begin{tabular}{|c|c|c|c|}
\hline No. & $\begin{array}{l}\text { The first city } \\
\text { Pre-ind ustrial } \\
\text { properties }\end{array}$ & $\begin{array}{l}\text { The second city } \\
\text { Industrial period } \\
\text { properties }\end{array}$ & $\begin{array}{c}\text { The third city } \\
\text { Post-industrial period } \\
\text { properties }\end{array}$ \\
\hline 17 & $\begin{array}{l}\text { Recyclable garbage } \\
\text { and waist; } \\
\text {-no plastic } \\
\text { materials }\end{array}$ & Production of non-recyclable material & $\begin{array}{l}\text { Environmental decay } \\
\text { due to high amount } \\
\text { of non-recyclable } \\
\text { materials }\end{array}$ \\
\hline 18 & Low purchasing power & $\begin{array}{l}\text { Average purchasing } \\
\text { power }\end{array}$ & High purchasing power \\
\hline 19 & $\begin{array}{l}\text { Religious wisdom } \\
\text { as a value }\end{array}$ & Capital as a value & $\begin{array}{l}\text { Knowledge of inventing } \\
\text { instruments } \\
\text { ( Hard \& soft wires) for } \\
\text { powers benefits }\end{array}$ \\
\hline 20 & $\begin{array}{l}\text { No air, water and } \\
\text { sound pollution (monoxide } \\
\& \text { dioxide) }\end{array}$ & $\begin{array}{l}\text { Starting of air, sound, } \\
\text { water and land pollution }\end{array}$ & $\begin{array}{l}\text { Contamination of water, } \\
\text { land and polluted air } \\
\text { and sound in big cities }\end{array}$ \\
\hline 21 & Joint families & Breaking of joint family & $\begin{array}{l}\text { Single, small and broken } \\
\text { families and change } \\
\text { of family age }\end{array}$ \\
\hline 22 & $\begin{array}{l}\text { Similar language } \\
\text { and accent }\end{array}$ & $\begin{array}{l}\text { Similar language } \\
\text { different accent }\end{array}$ & $\begin{array}{l}\text { Imposed language and } \\
\text { accent of political powers }\end{array}$ \\
\hline 23 & $\begin{array}{l}\text { Inward organic } \\
\text { limited expansion } \\
\text { within the city walls }\end{array}$ & $\begin{array}{l}\text { Expansion beyond } \\
\text { the city walls }\end{array}$ & Outward expansion of cities \\
\hline 24 & $\begin{array}{l}\text { High face to face } \\
\text { real social interaction }\end{array}$ & $\begin{array}{l}\text { Average social } \\
\text { interaction }\end{array}$ & $\begin{array}{l}\text { Face away false and } \\
\text { mendacious social interaction }\end{array}$ \\
\hline 25 & $\begin{array}{l}\text { Short distance } \\
\text { of place of work } \\
\text { and living }\end{array}$ & $\begin{array}{l}\text { Increased distance } \\
\text { of place of work } \\
\text { and living }\end{array}$ & $\begin{array}{l}\text { High distance of } \\
\text { place of work and living }\end{array}$ \\
\hline 26 & $\begin{array}{l}\text { High cooperative } \\
\text { society }\end{array}$ & $\begin{array}{l}\text { Medium cooperative } \\
\text { society }\end{array}$ & Low cooperative society \\
\hline 27 & $\begin{array}{l}\text { Low-rise apartment } \\
\text { housing }\end{array}$ & $\begin{array}{l}\text { Medium-rise apartment } \\
\text { housing }\end{array}$ & $\begin{array}{l}\text { High-rise apartment housing } \\
\text { (high F.A.R in green areas) }\end{array}$ \\
\hline 28 & Agriculture economy & $\begin{array}{l}\text { Large scale industrial } \\
\text { economy }\end{array}$ & Knowledge base economy \\
\hline 29 & $\begin{array}{l}\text { Thought oriented society } \\
\text { (not instrumental); } \\
\text { short gap between } \\
\text { taught and action }\end{array}$ & $\begin{array}{l}\text { Thought and instrumental oriented } \\
\text { society; } \\
\text { beneficial taught and actions }\end{array}$ & $\begin{array}{l}\text { Instrumental oriented society; } \\
\text { more of new theories } \\
\text { and less action for cities. }\end{array}$ \\
\hline 30 & $\begin{array}{l}\text { Mix land use without } \\
\text { major problem }\end{array}$ & $\begin{array}{l}\text { Mix land use with major } \\
\text { problem of zoning }\end{array}$ & $\begin{array}{l}\text { Dictated zoning \& non-practical } \\
\text { mixed land uses. }\end{array}$ \\
\hline 31 & Sense of orientation & Weak sense of orientation & Loss of sense of orientation \\
\hline 32 & Sense of belonging & Weak sense of belonging & Loss of sense of belonging \\
\hline 33 & Sense of place & Weak sense of place & Loss of sense of place \\
\hline
\end{tabular}


Table 1. Comparative analysis of various features of settlements in pre-industrial, industrial, and post-industrial periods (with reference to Figure 1) (continued).

\begin{tabular}{llll}
\hline No. & $\begin{array}{c}\text { The first city } \\
\text { Pre-industrial } \\
\text { properties }\end{array}$ & $\begin{array}{c}\text { The second city } \\
\text { Industrial period } \\
\text { properties }\end{array}$ & $\begin{array}{c}\text { The third city } \\
\text { Post-industrial period } \\
\text { properties }\end{array}$ \\
\hline \multirow{3}{*}{$\begin{array}{l}\text { Planning and designing } \\
\text { for man as a part of nature }\end{array}$} & $\begin{array}{l}\text { Man interfering in } \\
\text { nature and planning } \\
\text { and designing for automobile }\end{array}$ & $\begin{array}{l}\text { Planning and designing for } \\
\text { automobile and fast mood of } \\
\text { transportation irrespective of } \\
\text { natural environment }\end{array}$ \\
\hline 35 & $\begin{array}{l}\text { Settlements with } \\
\text { defined edges }\end{array}$ & Destruction of edges & $\begin{array}{l}\text { Not determined and } \\
\text { proper urban edges }\end{array}$ \\
\hline
\end{tabular}

addressing issues, such as economic viability; encouragement for regeneration; attention to environmental and socio-cultural aspects; and creation of cohesive, safe, clean, and green communities and urban forms.

\section{Discussion}

In the contemporary period, many new theories have been developed by various specialists in different fields all over the world to solve the created problems in industrial and post-industrial periods. Unfortunately, many of the piecemeal sorts of solution that we have adopted so far could not help to solve the problems to the scale required. Sustainable design (also called environmental design, environmentally sustainable design, environmentally conscious design, etc.) is the philosophy of designing the built environment and services to comply with the principles of social, economic, and ecological sustainability in the most accepted way to deal with our settlement design and urban fabrics.

\subsection{Unsustainability causes}

Various theorists in planning and designing, like Krier (1992) [2], Alexander Jencks (1986) [3], Norberg Schulz (1987) [4], Jakobs (1961) [5], MecHarg (1969) [6], Robert Owen (quoted from Pakzad [7]), John Ruskin \& Viliam Moris (quoted from Mosavi Hejazi \& Pourjafar) [8], and Ardalan and Bakhtiar (2014) [9], are against some of the modernist ideas. They have interesting ideas against modernism and claim that it has caused unsustainability. Some of them believe that the modernist rationalism has failed.

The following are the major global problems that have mostly appeared after Industrial Revolution:

- Increase in earth temperature;

- Destruction of vegetation cover;

- Soil erosion;

- Extinction of various kinds of animals and species;

- Injustice in economy and unequal division of resources;

- Consumption of recourses beyond requirements;
- Rapid urban population growth;

- Dependence on unrecyclable materials;

- Appearance of various types of pollution;

- Design and development without respecting nature;

- Limited people participation;

- Over-loading of the land by high-rise development and high F.A.R (Floor Area Ratio);

- Chang of green land to brown;

- Scio-economic problem and incompatible land uses of traditional core areas;

- Zoning, which is a kind of dictation and nonepractical mixed land use in big cities;

- The gap between the passive aim of modernism and what the modernists claim openly;

- The main aim of many of modernists, which is maximum benefit in the shortest time;

- Unsustainable socio-economic, political, and management conditions;

- Planed and designed cities for automobile and not human being;

- Failed mathematical and quantitative planning;

- Hopeless and useless modern life;

- Destruction of human scale and disrespect for tradition.

\section{Case study: Sustainable urban environmental design for Darabad River Valley}

\subsection{Darabad River Valley}

River Valley of Darabad is located on the foot of Alborz Mountain and east of District 1 of Tehran (Figure 2). River Valley of Darabad is a God given gift to the inhabitants of Tehran and many of those who enjoy their weekend over there. Darabad River Valley has a village where it reaches plain areas with less slope. The village had a population of 367 people in 1920 [11]. Mozafaroddin-shah built a small palace in this region 


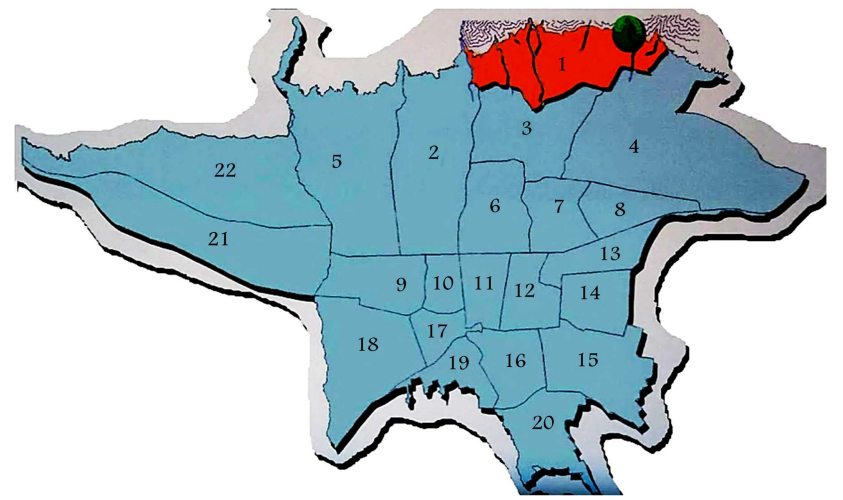

Figure 2. Location of the Darabad River Valley in Tehran [10].

in 1918 [12]. From the date, this place became popular and was populated beyond its capacity. Available land was used for agriculture and most of the area was covered with gardens and green farms at that time. Darabad river valley is one of the greatest 7 river valleys in the north of Tehran, which with the associated rivers can have a sustainable environment due to the characteristics of high quality of potable water, good subsoil, and rich green areas. This makes it an important issue to maintain and conserve this sustainable rich quality of environmental heritage.

This project aims to make the river valley (with high quality water, vegetation cover, and beautiful rocks, fountains, and falls), which was converting into a huge polluted urban drain, a leisure valley for the north-east of Tehran. A comprehensive wise and conscious approach is applied in this project. Issues such as economic viability; encouragement for regeneration; attention to environmental and socio-cultural aspects; and creation of cohesive, safe, clean, and green communities and urban forms were considered in this project.

\subsection{Darabad River Valley}

To study the existing situation, the entire site was divided into three zones after an overall observation. They were named zones A, B, and C (Figure 3). Zone A has a quite natural environment. Zone $\mathrm{B}$ is partly built and has semi-natural environment. Zone $\mathrm{C}$ is mostly manmade environment that is Darabad urban village.

Accordingly, by study of the existing situation to define the problems and prospects related to the headings mentioned above (in methodology of research), 3 volumes of report were prepared. However, in this paper, problems and prospects are given in brief: unfortunately, due to irrelevant encroachments, unplanned growth of the settlement, and many unauthorized buildings, the main function of the river valley of Darabad, which is providing the areas of natural and visual significance and green spaces with flow of clean and cool air plus water for drinking and agriculture, has been forgotten. Most of the riverfront built forms are not faced the river. Unfortunately Darabad river sides have become a place for garbage and drainage disposal.

Urban Village of Darabad, which is located beside Drabad River (Zone C) and within the valley, had an organic pattern of built form with fine grain and uniform texture. Previously, gardens dominated the built

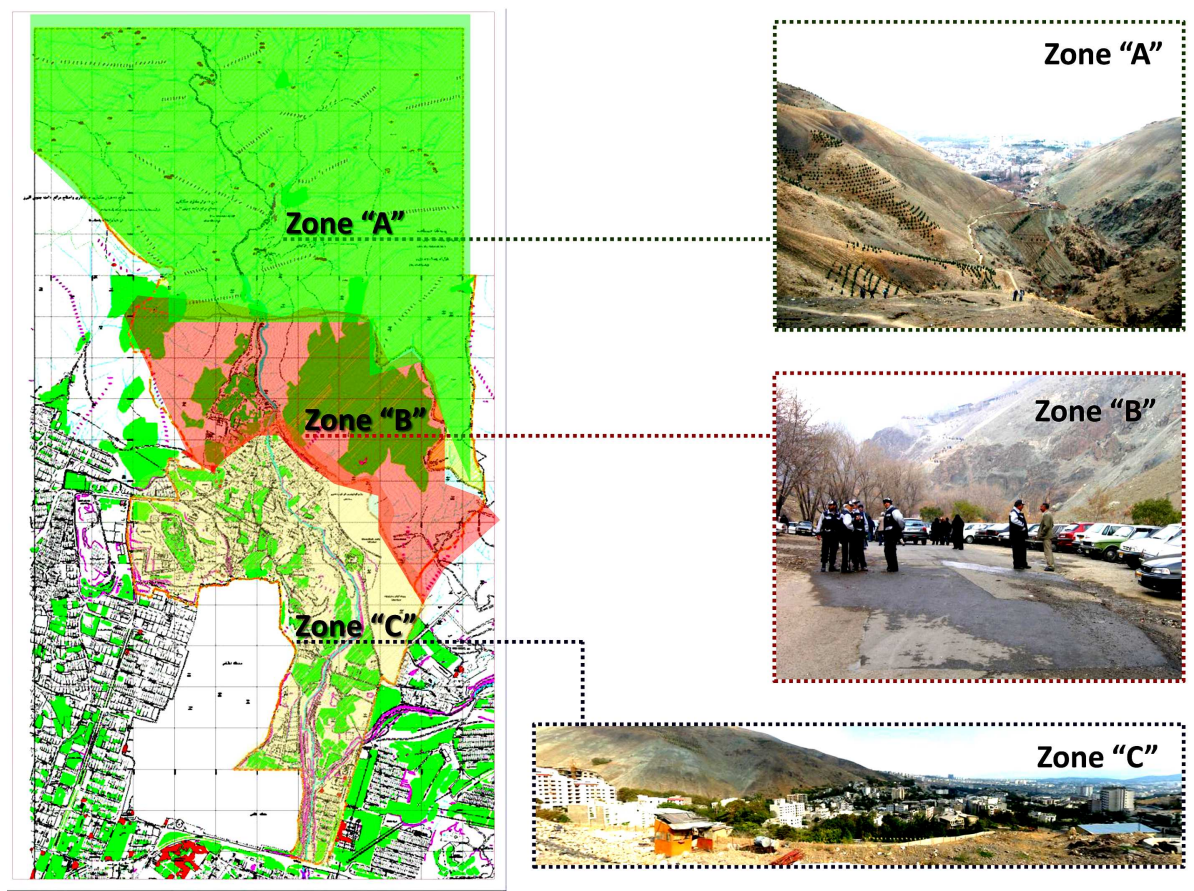

Figure 3. Zoning of Darabad River Valley [11]. 
form of the village. But, at present, it is encroached by high-rise development (buildings), which not only closes the interesting visual cone to the mountain and other natural views, but also is incompatible with the present narrow alleys. It also causes a sudden change in the beautiful skyline. Municipality, other organizations, and some of the inhabitants engaged in land and building speculation have closed their eyes and ears and forgotten the mad flow of 1986 in these areas, which killed many people and destroyed many houses. As it is already mentioned, one should be aware that designing is altering an existing system [13]. Some of the housing projects in Darabad have not been designed compatible with nature. Therefore, planning and design with respect to ecological requirements of the environment for conservation and revitalization of Darabad River Valley should be the main aim of the Municipality of Tehran. To achieve this goal, "Tehran River Valley Conservation Authority" (TRVCA) shall be formed. This organization will be responsible for achieving the aim and objectives of the river valleys conservation reported in this project. All the river valleys shall be linked to each other at the foothill of Alborz Mountain to form a green pedestrian corridor for recreation (Figure 4 ).

Famous architects like Corbusier tried to have Shivalik Hills as background for Chandigarh City in India. Tehran has a chance to have beautiful skyline of Alborz Mountain at its background through these river valleys. Therefore, building height in the purposed Zone C (Figure 4) shall be controlled to have good view and relation to open and green spaces and Mountain of

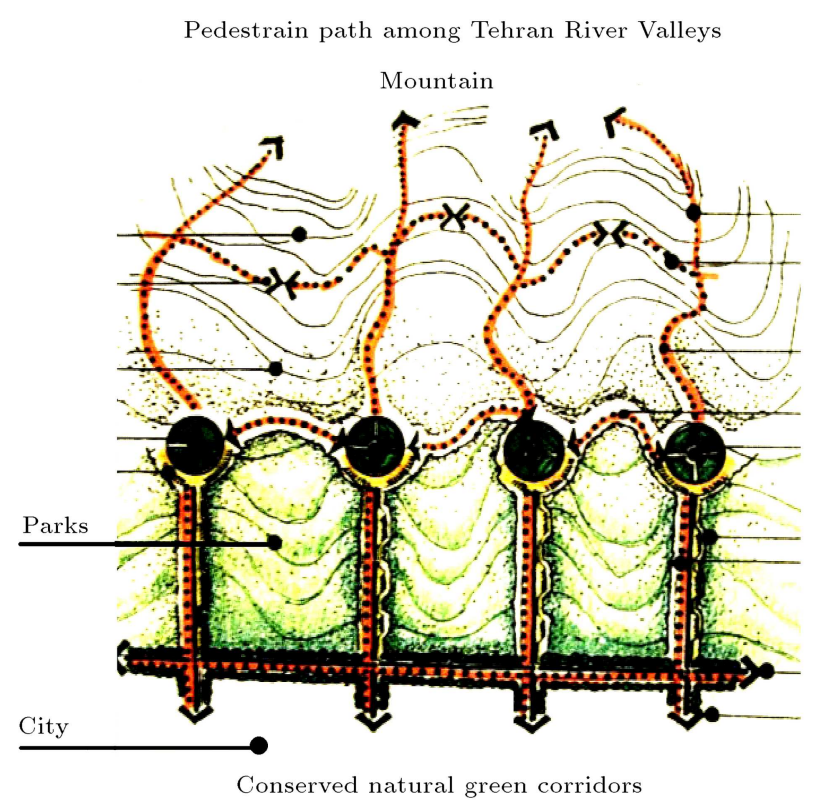

Figure 4. Purposed conceptual diagram for the river valleys of Tehran to be linked to each other, providing a recreational pedestrian pathway along the Alborz's foothills [14].
Alborz. A meandering undulating landscape stretching across the length of Chandigarh, which Aditya Parkash calls it: "The place of leisure and pleasure of strolling and picnicking of gossiping and frolicking. People should move leisurely from one end to another. Here shall be birds' paradise, a garden of flowers, perhaps a garden of Sculptures set in a landscape of fountains, falls, and sprinkling and hills and trees" [15]. We can have similar ideas for river valleys of Tehran, especially for one like Darabad that has yet some potential to be revitalized. In the process of an ecological approach, respecting natural values and climatic consideration of land form and local architecture shall be kept in view. Restricted roll and regulation to consider foothill urban design and architectural criteria is vital in these areas. Putting the river into a concrete channel without considering the rich landscape features of the site shall be inhibited (Figure 5).

Safety and security from flood, earthquake, and landslide shall be considered in any purposed plan. Educating and encouraging people to respect environment regarding disposing rubbish, cutting trees, and polluting clean and potable water of natural fountains in the valley shall be started. Connecting various open and green spaces to the main green corridor of the river valley is necessary. In this way, not only the major view to the mountain will be conserved, but also a continuous pedestrian path and cycle truck can be provided along the river passing through green spaces and gardens. This makes the valley of Darabad a leisure valley. Both sides of the riverfront shall develop as a green corridor (Figure 6) with a minimum width of 30 meters as the proposed "Zone A", and all the existing green spaces and dilapidated building areas shall be green in future. This is the proposed "Zone A" (Figure 5). Proposed leisure valley should have open public green spaces after every 10 minutes

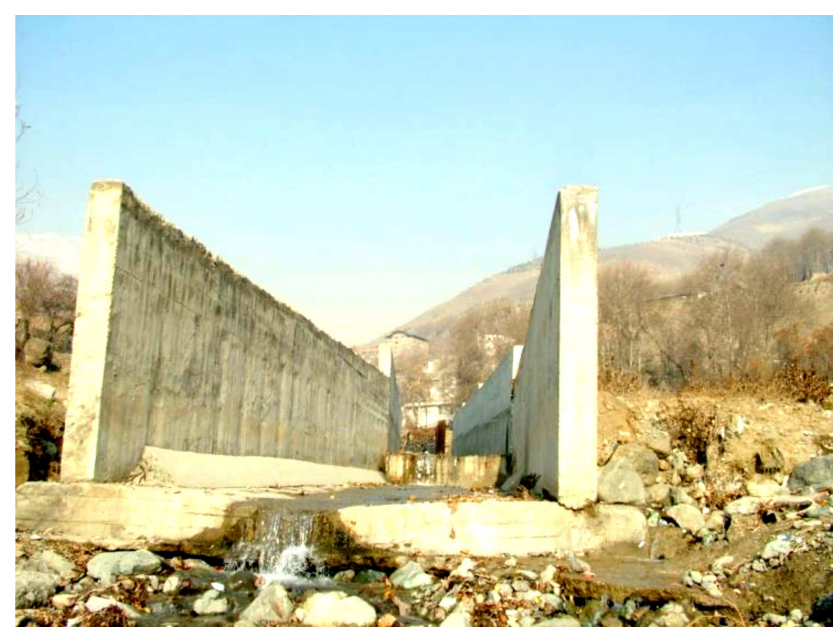

Figure 5. Concrete chancel for Darabad River Valley which is unaccepted approach and has been stopped as it was suggested in this project [16]. 

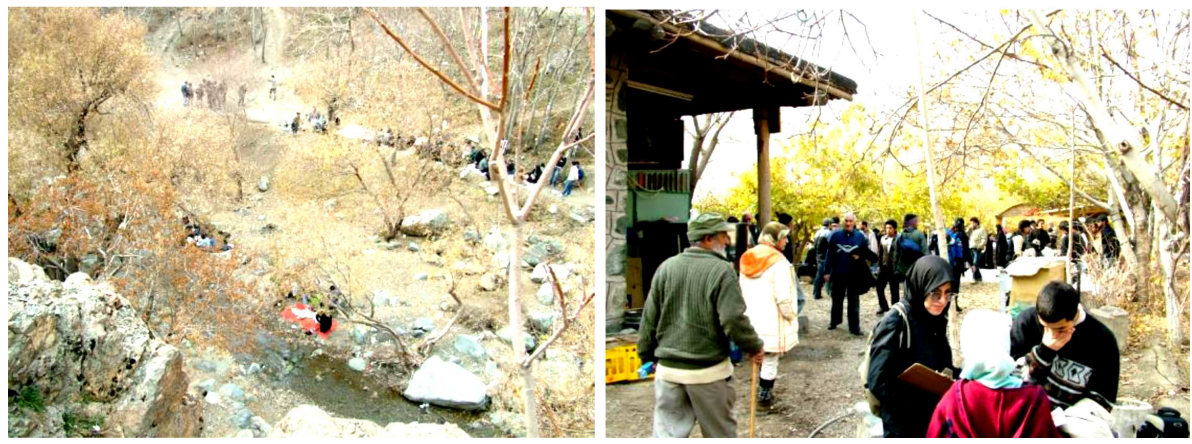

Figure 6. Various significant areas along the river [11]
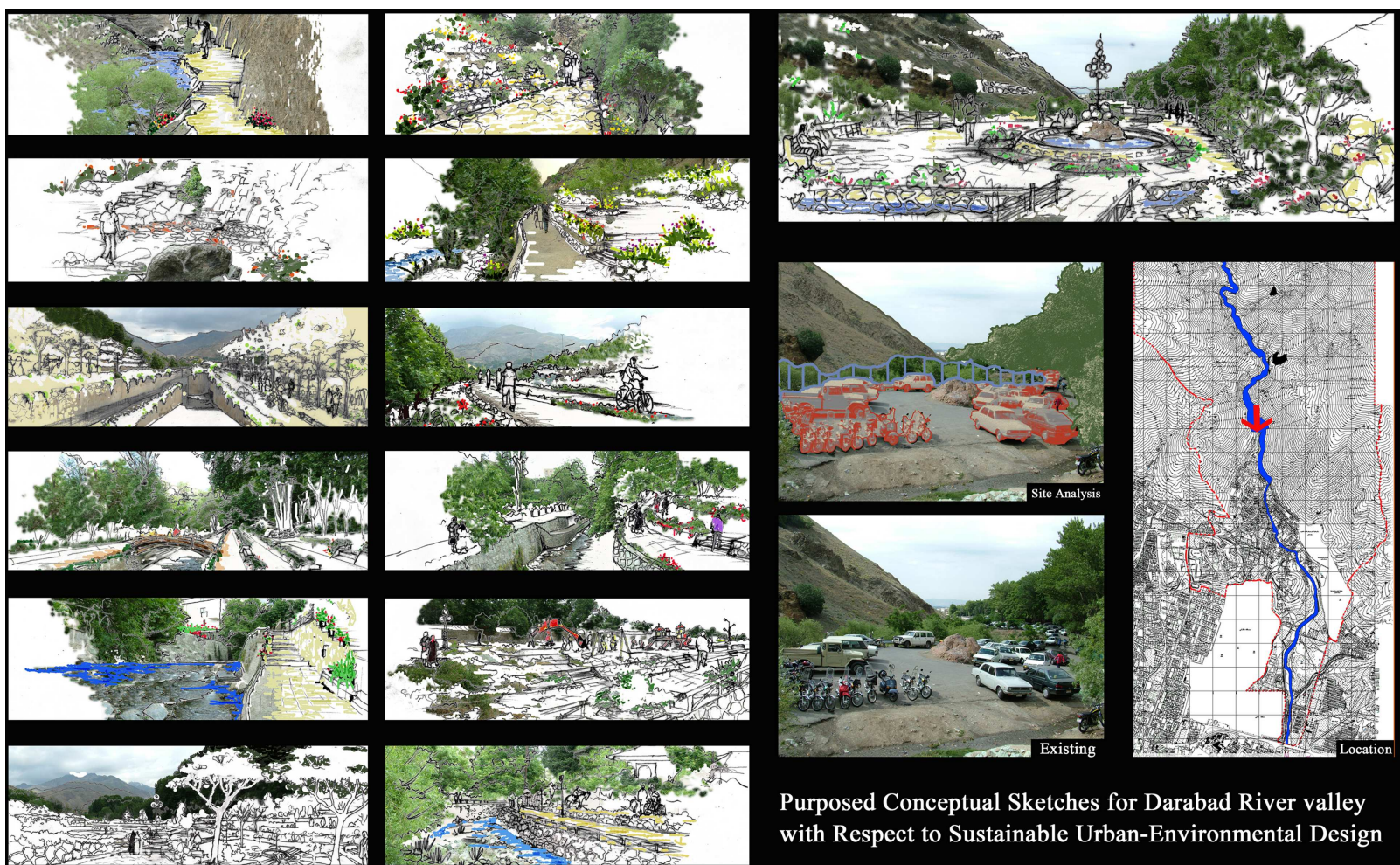

Purposed Conceptual Sketches for Darabad River valley with Respect to Sustainable Urban-Environmental Design

Figure 7. Sketches presenting urban environmental design ideas for various section of Darabad River Valley [17].

of walk so that people can have a chance for rest (Figure 6).

Building laws to control building height in such a way that important views and vistas remain open is necessary. Sustainable plantation and green spaces with local plants with some infrastructure to house people during earthquake hazards are required. Health care facilities, toilets, dustbins, fire distinguish, and other facilities such as restaurants shall be provided at various spots for the tourists and inhabitants that come to the valley in the weekend.

\section{Conclusion}

Limited resources such as air, water, and land would not allow over-populating, over-loading, and misbehaving the natural environment. The accelerated urbanization has brought several major problems that threaten future of the cities and lead to unsustainability. A sustainable city must take care of its valuable resources, especially those which are helpful in creation of green and clean spaces and cohesive built form. Many big cities of third world, like Tehran, have similar problems in their existing situation and development plans. Iranian history reveals that they have a brilliant past in respecting nature. They have always designed with nature. Places like Tehran's river alleys and especially Darabad shall be fully conserved, not only as a vital part of the present city, but also as a natural heritage for the future generation (Figure 7 ). River valleys of Tehran in District 1 can be the best recreational zone, where water and good soil for plantation and green spaces are available. These corridors would survive and join Tehran's proposed green belt. 
This will obviously help to improve microclimate of Tehran.

It is purposed to create a kind of convivial access from Darabad village to the hilly areas. The foot hill with its existing natural features (such as waterfalls, fountains, color full rocks bushes, flowers and trees) can be developed as a natural eco-park with attractive pedestrian cycle and horse truck. All the mentioned features can make the River Valley of Darabad an interesting leisure valley as a natural recreational area in Tehran. Finally, a comprehensive, wise, and conscious approach, similar to what we have used in Darabad River Valley Project, is suggested for all similar projects.

\section{Acknowledgment}

The authors would like to thanks Professor Dr. Mortaheb and Dr. Saeed Farmahin Farahani who encouraged us to prepare this paper. They also thank Sara Pourjafar and Mr. Peiman Pilechiha who helped them in preparation of this paper.

\section{References}

1. Pourjafar, M., Precept \& Performance of Neighborhood Unit, B. Arch. Thesis, Chandigarh College of Architecture, Chandigarh, India (1984).

2. Krier, L., Architecture \& Urban Design, MCM X CII Academy Edition, London, UK (1992).

3. Alexander Jencks, C., What Is Post-Modernism?, St. Martin's Press, New York, USA (1986).

4. Norberg Schulz, C., Modern Norwegian Architecture, Scandinavian University Press, Oslo, Norway (1987).

5. Jacobs, J., The Death and Life of Great American Cities, Random House, New York, USA (1961).

6. McHarg, I., Design with Nature, The Natural History Press, Garden City, New York, USA (1969).

7. Pakzad, J., An Intellectual History of Urbanism-From Utopia to Reality, (No. 1), Shahid Beheshti University, Tehran, Iran (2007).

8. Mosavi Hejazi, B. and Pourjafar, M.R. "The influence of Persian Islamic art on art and craft movement", Journal of Honarhai e Ziba, 12, pp. 4-22 (2002).

9. Ardalan, N. and Bakhtiar, L., The Sense of Unity: The Sufi Tradition in Persian Architecture, University of Chicago Press (1973).

10. Pourjafar, M.R., Bemanian, M.R. and Ansari, M. "River valley development, case study: Darabad", Ecocity, Banglour, India (2005).

11. T.M.U, Environmental Urban Design of Darabad River Valley, Municipality of Tehran, Tehran, Iran (2006).
12. Sotodeh, M., Tehran and Shemiranat, Anjoman-EAsare Melli, Tehran, Iran (1974).

13. Bane, R. "Landscape arch", Architecture + Design, 7, pp. 20-32 (1985).

14. Baft Shahr, Consultant Eng., Urban - Environmental Design of Velangak River Valley, Municipality of Tehran, Tehran, Iran (2003).

15. Parkash, A., Chandigarh; A Presentation in Free Verse, Chandigarh Administration, Bombay, pp. 4750 (1980).

16. Gozineh Consultant Eng., Conservation of Golabdareh, Municipality of Tehran, Tehran, Iran (2004).

17. Pourjafar, M.R., Urban Environmental Design of Water Front, Tarbiat Modares University Press, Tehran, Iran (2014).

\section{Biographies}

Mohammadreza Pourjafar was born in 1956. He gained good experiments in painting and sketching during his high school studies in Mathematics. His research interests are art, arch., urban design, and planning. He received the Gold Medal of CCA (Candigarh, India, 1983), Punjab University Medal, and Indian Institution of Engineers Medal in 1984. He did MUD at SPA in 1986 and PhD at IIT Roorkee, India, in 1992. Prof. Pourjafar has published more than three hundred scientific papers. He has published 10 books in architecture and urban design. He has also been awarded for one of his books, named "Urban Environmental Design of Water Front". He was head of Faculty of Art \& Arch. (T.M.U) until 2008 and HOD of Urban Planning and Urban Design till May 2015.

He has also worked on the following projects: design of private houses, development plan of Bandare-Lengeh and Kong, and comprehensive plan of settlement along the northern side of the Persian Gulf. Also, he has the experience of corporation in planning and side selection of Millad Communication Tower, landscape design of Tarbiat Modares University, planning of Modares Science and Technology Park, environmental planning and urban design criteria identification for Darabad River Valley, and preparation of a comprehensive plan for Sahand New City (Until 2008). He was selected and awarded by president of IR Iran as a distinguished professor at national level in the field of research in Art \& Arch. in Iran in 2010 and also in 2014.

Ali Pourjafar was born in 1989 in India. After his Mathematic \& Physic Diploma, he did BArch at PNU in 2011 and MUD at Tarbiat Modares University in 2015. He is the co-author of two books named "Architecture and Urban Design of Islamic Period 
in India" and "Manifestation of the Iranian-Islamic Subculture in Designing Urban Spaces". He has published about 30 scientific articles about architecture and urban design. He has also cooperated in a few research projects such as rediscovery of Persian Islamic vocabulary of urban design with reference to the Shiraz School of Urban Design, and study and development of urban planning and design criteria of Iranian-Islamic city. Ali Pourjafar was nominated as a distinguished student at the national level in Iran in 2012. 